\title{
The Problem of Water Management in Diverse Societies: Study of Kalabagh Dam Project in Pakistan
}

\author{
Muhammad Nawaz Bhatti (Corresponding author) \\ Lecturer in Political Science, University of Sargodha, Pakistan
}

Tel: 004565502830 E-mail: shakeebnawaz@gmail.com

Received: December 01, 2011 Accepted: December 28, 2011 DOI: 10.5296/jpag.v1i2.1220

\begin{abstract}
The horrible flood of 2010 in Pakistan has revived the debate about the utility of Kalabagh dam project that was, earlier, shelved by the present government. Pakistan is facing acute energy crises and water shortage. Being an agrarian economy, it requires electricity and water for the irrigation purposes. It has been argued that Kalabagh dam can deal with the most problems of Pakistan associated with the energy crises. But, there is a considerable resistance against this project in the smaller units of the federation. The difference of opinion over the distribution of water and Kalabagh dam project is mounting distrust among the federating units. This paper attempts to analyze the objections of smaller units over the construction of Kalabagh dam project. This analysis intends to explore whether the objections are valid or are just the misgivings. Analytical and comparative approach is adopted in the presentation of arguments.
\end{abstract}

Keywords: Kalabagh dam; Water Management; Pakistan 


\section{Introduction}

It has been observed elsewhere that the large dams are very useful for agrarian economies having the wealth of water in abundance. They are not only the source of cheapest power generation but are also used to store water in the rainy seasons and supply it during the dry seasons for irrigation to promote agriculture. So, it can be argued that Pakistan requires large dams to overcome the problem of energy crises at the moment. The importance of large dams like the project of Kalabagh dam is growing with the passage of time. Kalabagh dam is a multipurpose project which will produce 3600 MW cheap electricity and will supply 6.1 MAF water supplies for irrigation. Unfortunately, this most important mega project has been politicized since its inception. On one side province of Khyber Pakhtunkhwa and Sindh are opposing this project and on other hand, the federation and Punjab province have been remained in favor of the project's construction. So, it has become the major bone of contention among the provinces of Pakistan ${ }^{\mathrm{i}}$.

The smaller federating units have certain grievances ${ }^{\mathrm{ii}}$. Except Punjab, all the constituent units of Pakistan have many reservations over the construction of Kalabagh dam. The provincial assemblies of Sindh, Khyber Pakhtunkhwa and Balochistan have passed resolutions against the construction of Kalabagh dam iii and Punjab Assembly has passed a resolution in favor of its construction $^{\text {iv }}$. This difference of opinion led the government to abandon the project. But, the water flood of 2010 has once again demonstrated the importance of the project. Wastage of a huge quantity of water and loss of many lives and great amount of property has greatly enhanced the importance of the large dams like Kalabagh dam in Pakistan. It is estimated that about 59 million-acre feet water has passed below the Kotri Barrage ${ }^{v}$. According to a rough survey, about 20 million people were affected directly by this flood and they also faced loss of billions dollars of their property and agricultural crops. About 1600 people were lost their lives. ${ }^{\text {vi }}$ This huge quantity of fresh water could fulfill six dams of Kalabagh dam's capacity, which could be used in the dry climatic spells for agricultural purposes and energy generation.

\section{Disagreement over the Water Distribution}

Distribution of resources among the federating units has been remained problematic in Pakistan. It is partly due to the uneven development that the state exhibit and partly because of the dissimilarity in the size of population of the constituent units and overrepresentation of dominant group, Punjabis, in the state apparatus. The relatively poorer and marginalized groups based in smaller provinces have certain community concerns and territorial grievances. The province of Punjab has been perceived by smaller provinces as a dominant contender. It has been argued that this relative advantageous position of the Punjabis has annoyed the people of deprived regions and the marginalized communities. The grievances of "ethnic minorities and/or smaller units include the pre-dominance of Punjabis in the civil-military bureaucracy, the comparative development level of Punjab, the 'contentious' formula that regulates the distribution of funds to provinces, and distribution of water between Punjab and the smaller units" (Mushtaq, 2010). However, the Pakistani federation's efforts to resolve the contentious issues and to accommodate the marginalized groups are appreciable. The 
agreement of provinces over the multiple criteria for distribution of funds in National Finance Commission Award is a successful story. Similarly, the abolition of concurrent legislative has provided more autonomy to the provinces. The Aghaz-e-Huqooq-e-Balochistan (the Start of Rights of Balochistan) package can uplift the poorest region of the Pakistan. However, water management has been remained a challenge for the political leadership of Pakistan. Various committees and commission were constituted but 'ad hoc sharing arrangements was followed up to 1990' due to lack of consensus ${ }^{\mathrm{vii}}$. However, IJI alliance successfully evolved consensus between the center and the provinces over the thorny issues of the allocation of Indus water in 1991 (Rais, 1993). The federal and provincial governments reached at an agreement that was ratified by the Council of Common Interests $(\mathrm{CCI})^{\text {viii }}$. But, despites of this agreement, the difference of opinion over the construction of Kalabagh dam remained alive. Various military and civilian regimes remained reluctant to start the project because of the harsh opposition of the minority provinces. The refusal of Ghaus Ali Shah, chief minister of Sind during Zia-ul-Haq period, to approve the proposal of the construction of Kalabagh dam led to his dismissal in $1988^{\mathrm{ix}}$. Equally, the chief minister of Khyber Pakhtunkhwa did not accept the plan. In addition, the people of Sindh and Khyber Pakhtunkhwa participated in anti Kalabagh dam rallies and demonstrations. On the other hand, the federation and Punjab continued their support for the project (Ahmad, 2004). In the following years, "Benazir Bhutto (1993-96), Nawaz Sharif (1997-1999, and Pervez Musharraf (1999-2007) remained unable to develop a consensus among provinces over the construction of Kalabagh dam" (Mushtaq, 2010). Eventually, the Gillani administration has announced to abandon the construction of the Kalabagh dam.

\section{The Project of Kalabagh Dam}

The Kalabagh dam project was proposed on the Indus River. The Rigvida is the $1^{\text {st }}$ book in which River Indus is mentioned. It is associated with Sapta-Sindhu, the ancient name for the Indus basin. Sapta-Sindhu means a land of seven rivers, which are: Indus (Sindhu), Jhelum (Vitasta), Chenab (Asikni), Ravi (Parsuni), Sutlej (Sutudri), Soan (Susoma), and Sarasvati (today represented by the dry bed of Ghaghar). So, the Aryan invaders gave it the Sanskrit name Sindhu, meaning ocean (Bengali, 2003, p. 5). It originates from Lake Mansarovar in Tibet and enters the main synclinal valley between Zaskar and Ladakh Ranges in the Northern Areas. There are so many tributaries of Indus, which join it in its course from the Lake Mansarovar to the Arabian Sea. Its total length is about 2897 kilometer (Salman \& Uprety, 2005, p.12).

To identify the best site for Kalabagh dam project, engineering investigations were started in 1953 and two sites were identified, one is about five miles and the other is about three miles below the present site. Associated Consulting Engineers Limited (ACE) was appointed in 1972 to make feasibility of the project. ACE identified two suitable sites for the project. Site $\mathrm{C}$ was located below the confluence of the River Indus and River Soan and site D was located above the confluence. After the detailed investigations, site $\mathrm{C}$ was declared most suitable for the construction of the project. ACE published its feasibility report in 1975. In 1982, Kalabagh Consultants (a joint venture of five engineering firms including ACE) was appointed for the detailed study. Their task was based on three stages. Stage one of three 


\section{Macrothink}

tasks was to produce detailed planning report of the project and stage two was to prepare detailed designs of the project components with specifications and tender documents of the civil work and outline specifications for the electrical and mechanical plant. In stage three, tender designs were refined based on further model testing, laboratory testing and field investigations and detailed designs, specifications and tender documents for the mechanical and electrical plants were prepared ${ }^{\mathrm{X}}$.

Finally recommended site for Kalabagh dam project is located on the River Indus at about 210 Kilometer downstream of Tarbela dam and about 26 kilometer upward of the Jinnah Barrage. Its proposed height will be 260 and it will be a rock-fill dam. Its maximum estimated retention level will be 915 feet from the sea level and its useable storage capacity will be 6.1 million acre feet (MAF).

Two spillways on the right bank are proposed to discharge the floodwater. The maximum discharge capacity will be 2 million cusecs in the highest floods. On the left side, construction of a powerhouse is proposed, with the power generation capacity of 3600-mega watt (WAPDA, 1999).

\section{Figure 1: Map of Kalabagh Dam}

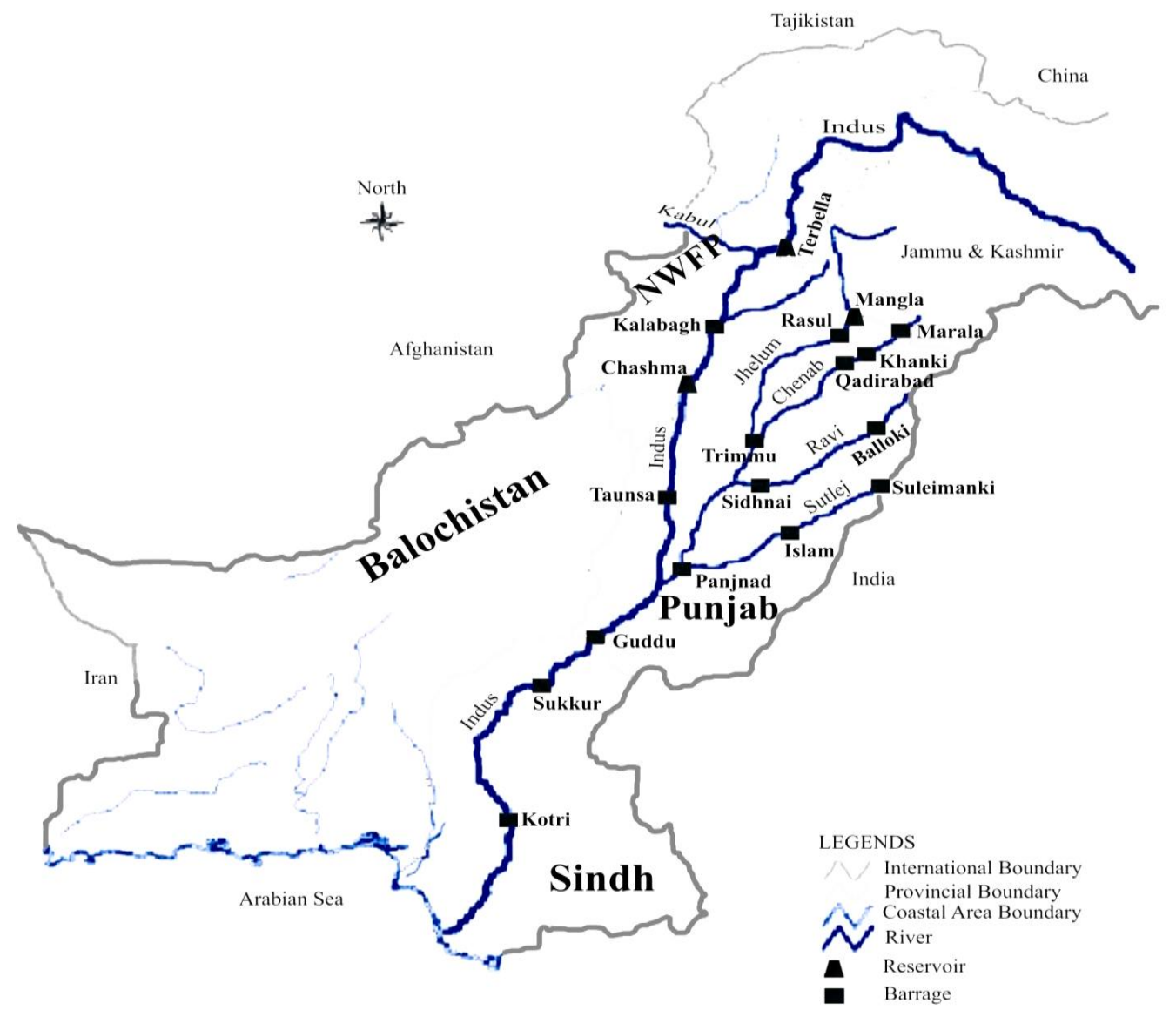

Source: (Mushtaq, 2010). 


\section{Evaluation of Reservations against Kalabagh Dam Project}

Pakistan is consisting of four provinces namely, Punjab, Sindh, Khyber Pakhtunkhwa, and Balochistan. Punjab is the largest province and relatively developed region of the state. It is the major proponent of project of Kalabagh dam. The Punjab argues that various technical and parliamentary committees have recommended the feasibility and viability of the dam. It is also argued that the reservations of smaller units are mere exaggeration. Even, the Water Accord of 1991 clearly states the 'need of new water reservoirs, where ever feasible on the Indus or any other river of Pakistan' (Khan, 1991, p.32). It has been argued that 'this accord favored Sindh, and the province of Sindh received a larger share of water for cultivation' (Ghori, 2005). It seems that Punjab sacrificed to get favor for Kalabagh dam in return. Nevertheless, it was 'the most studied - it was subjected to a series of most exhaustive studies spanning three decades (1953-1982) - and a technically sound project' (Hashmi, 2002).

Balochistan is the largest province by area but the smallest in terms of population. It is the poorest region and least concerned about the dam because it is not a riparian of the River Indus. However, it receives a considerable amount of irrigation water through the Pat Feeder canal at Guddu Barrage. Balochistan visualizes that in the post Kalabagh dam scenario, 'it's requests for more water from Indus River System will meet little successes' and even could result in a 'further reduction in its share of irrigation water usage. ${ }^{\mathrm{x}}$

The provinces of Khyber Pakhtunkhwa and Sindh are the harsh critics of the project. The objections of these provinces have been analyzed in this section subsequently.

\subsection{Apprehensions of Khyber Pakhtunkhwa}

Khyber Pakhtunkhwa is a multiethnic province. The three main linguistic groups include Pashtuns, Hindko-speaking ${ }^{\text {xii }}$, and Siraikis. The regional distribution of these groups has been enumerated in the table. The Pashtuns are more concerned about the Kalabagh dam because they are concentrated in the Peshawar valley and soundings and are supposed to be the main sufferer of the project in the province. Awami National Party (ANP), the heir of National Awami party, has remained at forefront in the opposition of the dam in province. However, the provincial leadership of the mainstream parties such as Pakistan People's Party and Pakistan Muslim League has also reservations over the construction of dam. The issue is politicized and the parties of the province denounce the project to influence the constituency politics. Major grievances of the various groups of Khyber Pakhtunkhwa have been analyzed in this section.

Table 1: Khyber Pakhtunkhwa by Mother Language

\begin{tabular}{lllllllll}
\hline Language & Pashto & Others & Siraiki & Urdu & Punjabi & Sindhi & Balochi & Total \\
Overall & 73.9 & 20.4 & 3.9 & 0.8 & 1.0 & - & - & 100 \\
Urban & 73.5 & 15.1 & 3.1 & 3.5 & 4.6 & 0.1 & - & 100 \\
\hline
\end{tabular}


Source: (Kennedy, 2002)

The major concern of this province over the project of Kalabagh dam voiced during several demonstrations and dialogues at various forums is that this project endangers the existence of Nowshera ${ }^{\text {xiii }}$ town. The protesters make reference to the flood of 1929 and argue that the Nowshera town and surrounding area will face serious threat to their survival in case of high flood. It will happen, they maintains, because the backwater effect of the Kalabagh reservoir will affect the water level in the Kabul River. Resultantly, the rise of water level in the river will threatened the survival of the town.

However, various investigations seem to disapprove this objection. A study conducted by Water and Power Development Authority of Pakistan (WAPDA) asserts that the 'backwater effect' of Kalabagh Lake will not affect the Nowshera town and surroundings. A state-of-art computer based study seems to suggest that the backwater effect would end about 10 miles downstream the town (WAPDA $(1999$, p.5).

The International Panel of Experts (POE) that was consisting of a well reputed experts such as Dr. Kennedy of USA and Chinese Expert Dr. Lianzhen also discarded the objection. It is pertinent to point out that the government of Khyber Pakhtunkhwa was consulted before the selection of the panel.

Malik (2005,p.1) ${ }^{\text {xiv }}$ also observes that the proposed designs of the Kalabagh dam Project demonstrate that the normal level of water in the reservoir would remain 10 miles downstream of Nowshera and there is no need of any protective measure to save the Nowshera town. Additionally, if the proposed Munda Dam project on River Swat is constructed it would prove an additional protection against any flooding (Malik, 1999).

The people of Khyber Pakhtunkhwa are also worried about the Mardan Salinity Control and Rehabilitation Project. They emphasize that the water level in the Kalabagh dam reservoir will be higher than the ground levels of the surroundings such as Mardan, Pabbi and Swabi areas. Consequently, the Mardan Salinity Control and Rehabilitation Project will be at risk.

However, the WAPDA (1999) disapproves this concern categorically. The study reveals that that maximum level of water in Kalabagh reservoir will be 915 feet above the mean sea level and the lowest ground levels at Mardan, Pabbi and Swabi areas are 960, 970 and 1000 feet above the mean sea level respectively. So, Mardan, Pabbi, and Swabi areas are 55, 45 and 85 feet higher than the maximum conservation level of the Kalabagh. This maximum water level of Kalabagh reservoir will be remained only for 3 to 4 weeks during the September and October after which it will reduce due to the release of water for Rabi crops and to power generation. Ultimately, it will reach at dead storage level of 825 feet by early June. This operation pattern of reservoir cannot block the land drainage and cannot become a cause of water logging and salinity in the areas of Pabbi, Mardan and Swabi (WAPDA, 1999, p.5). Water logging and salinity can only happen if the ground levels of Mardan, Pabbi, and Swabi are lower than the maximum reservoir level. But Pabbi with the lowest land level is at least 45 feet above the reservoir water level. So, it is impossible that any submergence or blocked drainage will be occurred by Kalabagh reservoir in these areas (Malik, 1999). 
A further objection raised by the Khyber Pakhtunkhwa is that the proposed Kalabagh dam project would adversely affect the operation of Mardan SCARP. Responding to this objection WAPDA (1999) claims that the out flow levels of main drains of Mardan SCARP are higher than reservoir elevation of 915 feet and the backwater level in Kabul River and Kalapani Khwar. These drains would keep on functioning without any obstruction. Favoring to this point of view it has been argued that that invert levels of the main drains of Mardan SCARP are 35 feet higher than the maximum elevation of the Kalabagh reservoir. So, Mardan SCARP drains would remain operational without any fear of blockage by reservoir (Malik, 1999).

An additional important concern voiced by the Khyber Pakhtunkhwa is that its 4500 acres of land will be submerged in the reservoir of the Dam in which 100 acres is prime irrigated land.

According to WAPDA (1999), from the dam site, the reservoir of Kalabagh dam Project will extend 92 miles up the Indus River and 36 miles up the Soan River, and about 10 miles up the Kabul River from the Kabul-Indus confluence. At its maximum level of 915 feet from the mean sea level, the reservoir area would be 164 square miles. Total cultivable affected land under the reservoir will be only 35,000 acres but permanently submerged cultivable land at the maximum elevation of 915 feet would be 27,500 acres. From which 24,500 acres will be in Punjab and 3000 acres in Khyber Pakhtunkhwa. From this cultivable land only 3000 acres are irrigated land (2,900 acres in Punjab and 100 acres in Khyber Pakhtunkhwa). The balance 7,500 acres are the land that will be temporarily submerged by floods with recurrence interval of 1 to 5 years. This land shall be taken under easement. The owners of this land will be fully compensated. They will also be allowed to cultivate this land as before. Out of 7500 acres of such land only 1,500 acres are in Khyber Pakhtunkhwa and rest of 6,000 acres are located in Punjab. In addition, the drawdown of the reservoir level every year would provide one season cropping in about 14,000 acres lying about elevation 890 feet. It is estimated that about 1,000 acres of prime irrigated land were acquired for Mardan SCARP alone, and compared to this; Kalabagh dam demands much smaller sacrifice (WAPDA, 1999, p.6).

B. A. Malik also supported this point of view. He says that no example can be traced anywhere in the world that a storage dam has been constructed without acquiring some land but the benefits of such dams far outweigh disadvantages. In case of Kalabagh dam maximum land would be submerged in Punjab. Eleven percent (3000 acres) of the total submerged area (27,500 acres) at the maximum reservoir level for 3 to 4 weeks in a year is located in Khyber Pakhtunkhwa and the other 89 percent (24,500 acres) is in Punjab. In case of irrigated land, only 3 percent (100 out of 3000 acres) in Khyber Pakhtunkhwa and 97 percent (2900 acres) in Punjab would be affected. It may be pointed out that about 5,000 acres of fertile lands is acquired for the construction of Islamabad-Peshawar Motorway (Malik, 1999).

One more concern is voiced by the province of Khyber Pakhtunkhwa is about the population dislocation. As Abrar Kazi stated that about 34,500 people will be directly displaced by the construction of the Kalabagh dam reservoir and there are many more that will not be directly affected by the project but are totally dependent upon the river for their livelihood. For 
example fishermen and boatmen will face heavy economic losses and be forced to migrate. He further stated that the affectees of Tarbela who were displaced in 1970 were provided alternate land in the Guddu Barrage command area in Sindh. Due to the drastic change in socio-cultural environment, inhospitable weather conditions, and hostile local population, majority of those people sold their lands and moved back. Moreover, there are about 3000 cases concerning these displaced people that have yet to be finalized (Kazi, 2003, p.182).

According to a study conducted by WAPDA in 1999, about 120,320 peoples will be dislocated of which 78,170 will be from Punjab and remaining 42,150 will be from Khyber Pakhtunkhwa. Arrangements have been made to compensate all affectees Compensation shall be paid to all the affectees for their properties like land, trees, buildings and other structures at market price in compliance with the Land Acquisition Act. It is also in consideration to offer minimum 12.5 acres of land to every land owning family. For this purpose about 74,000 acres of irrigated land will be required. The non-agriculturist affectees would be trained in various trades in the training institutes which will be established in the model village. These measures will provide maximum job opportunities for affectees where they would also be able to invest their compensation money. The affected families will be resettled in the various model villages and townships, which will be specially constructed along the peripheral areas of the reservoir.

In order to facilitate the resettlement of the displaced persons, a Resettlement Action Plan shall be executed. A total amount of Rs.403 billion will be allocated for resettlement and relocation of the disrupted population, which is widely spread over the reservoir (WAPDA, 1999, pp 7-8).

\subsection{Apprehensions of Sindh}

Sindh is the second largest province of Pakistan by population. Sindhis and Urdu speaking Mohajirs are the major groups based in the province. Mohajirs are mainly settled in urban centers of Sindh, particularly Karachi and Hyderabad. Therefore, they less concerned than the Sindhis about the construction of Kalabagh dam. However, being the second largest group of the province, they have supported the Sindhis' stand in this regard. Sindhis are son of soil and supposedly major sufferer of the project. Sindhi nationalist groups are more vocal against the dam. Even, the Sindhi leadership of the Pakistan people's Party are against the construction of dam.

Table 2: Sindh by Mother Language

\begin{tabular}{llllllllll}
\hline Language & Sindhi & Urdu & Pashto & Others & Siraiki & Punjabi & Balochi & Total \\
Overall & 59.7 & 21.1 & 4.2 & 4.9 & 1.0 & 7.0 & 2.1 & 100 \\
Urban & 25.8 & 41.5 & 11.5 & 8.8 & 1.7 & 11.5 & 2.7 & 100 \\
\hline
\end{tabular}

Source: (Kennedy, 2002 
River Indus plays an important role to develop the rural economy of the Sindh. Majority of the people in Sindh earn their livelihood by the agriculture and irrigation cannot be practiced without the sufficient availability of fresh water. Indus is the main source of water for the agriculture in Sindh. So the people of Sindh are very conscious about the availability of water in the river Indus. In the second half the $19^{\text {th }}$ century when British started the construction of barrages and canals to expand the irrigation facilities in the Indus Basin, concerns were voiced by the Sindh as a lower riparian. It raised objection on all those projects that were built to store or divert waters of Indus for any purpose. After the partition of India, Punjab became the upper riparian and Sindh lower riparian. Similarly, the other important projects of irrigation constructed after the partition, the people of Sindh also heavily criticize Kalabagh dam Project. Major grievances of the various groups of Sindh have been analyzed in this section.

The first objection raised by the Sindh province is that there is no surplus water to store in the Kalabagh dam reservoir. As Abrar Kazi stated that total available water measured at the rim stations of the three western rivers (Indus at Kalabagh, Jhelum at Mangla and Marala) 4 out of 5 years (80 percent probability) is about 123.59 MAF (Million Acre Feet). The Water Accord of 1991 signed among the four provinces of Pakistan apportions 114.35 MAF water for their needs and WAPDA also indicated $10 \mathrm{MAF}$ as system losses. The balance (124.35123.59) is negative 0.76 MAF which is flowing into the Arabian Sea (Kazi, 2011).

WAPDA claims that an annual average of 35 MAF has passed below Kotri to sea in the post Tarbela years. During the monsoon season (July to September) flood surplus is always available. Kalabagh reservoir will use only 6.1 MAF and nearly 29 MAF will be available to run downstream of Kotri Barrage. B. A. Malik opines that after the completion of Tarbela Dam, many studies of water flow in the River Indus below the Kotri Barrage describe that about 36 MAF water passed annually to the sea from 1977-78 to 1991-93. It shows that there is enough water to fill the Kalabagh reservoir. Under the Water Accord of 1991, Kalabagh dam will provide 2.1 MAF additional water to the province of Sindh for its Rabi and early Kharif needs. And about 7 lac acres of additional land would be brought under cultivation (Malik, 1999).

The second reservation of Sindh over the construction of Kalabagh dam is that it would deprive Sindh of her share of water and the province would change into a desert.

Dams do not consume water. They only store water during the flood season and supply it on the demand of crops during the dry period. The example of the operation of Tarbela Dam is enough to justify the construction of Kalabagh dam. Before the construction of Tarbela and Mangla from 1960 to 1967, average annual canal withdrawals of Sindh were 35.6 MAF. After the completion of Mangla and Tarbela the share of Sindh rose to 44.2 MAF with over 24 percent increase. Infect, in case of Kalabagh dam, the canal withdrawals for Sindh would further increase by about 2.25 MAF. Thus the reservation regarding the desertification of Sindh defies even the basic logic of a storage reservoir (WAPDA, 1999, p.9).

The third apprehension is about the High level outlets. It is said that High level outlets would be used to divert water from the reservoir and in that situation Sindh will deprive of her share 
of water.

On the other side WAPDA(1999) claims that there is no any provision in the design of project regarding the high level outlets for diversion of water from the reservoir. A modern electronic telemetry system has recently been installed at each barrage and other flow control points. This system monitors discharge of water in various canals commands, on real time basis under the auspices of Indus River System Authority (IRSA). This system shall also be extended to Kalabagh dam Project for the fair water distribution (WAPDA, 1999, p.9).

Another objection, which is raised by the Sindh on the construction of Kalabagh dam, is the reduction of flood cultivation in sailaba (riverain) areas. "Sailaba" crops are generally sown in the land adjacent to the main river and in the creeks near the coast of Arabian Sea. Although these crops are sown on the soil moisture of floods but cannot mature without more than one watering. As a result these lands give poor yields. Consequently, farmers irrigate their fields through shallow tube wells or lift pumps. Prime movers on these tube wells have to be removed during the flood season to avoid damage. There is about 660,000 acres of "Sailaba" cultivated land in Sindh from Guddu Barrage to sea. Tube wells facility has been provided in the majority areas for supplementary irrigation. Initially, these areas are sown by the moisture of floods when river over flows up to 300,000 cusecs. Floods peaks above 300,000 cusecs would still be coming after the construction of Kalabagh dam, without damaging the present agricultural practices. On the other hand large floods would be effectively controlled. In this situation permanent installation of tube wells will become possible to provide perennial irrigation facility in riverain area. The farmer can harvest two crops annually instead of the present one crop (WAPDA, 1999, p.9). Malik (1999) also favors this point of view and opines that the total sailaba area in Sindh is estimated about 600,000 acres. Residual soil moisture is used to sow the crops which is stored when the river discharges exceed 300,000 cusecs (cubic feet/second). He further describes that all of the riverain arable area is not purely sailaba. For example, in 1980-81 total cultivated area was 200,000 acres. Only 80,000 acres were sailaba and the remaining 120,000 acres were irrigated by shallow tube wells. These tube wells were installed to mature crops. Because sailaba land does not maintain enough soil moisture to sustain crops without additional watering. After the construction of Kalabagh dam, only 6.1 MAF or 7 percent of flood season flow would be stored. As a result, flood discharges of 300,000 cusecs or above will remain continue. However, high floods will be controlled. Due to the reduction in high flood peaks, installation of more durable pumping facilities will be possible without removing them before flood season every year.

An additional objection on the construction of Kalabagh dam is about the reduction of river flows below Kotri barrage. It would cause sea water intrusions which adversely affect the quality of groundwater. The fear that Kalabagh dam will cause sea water intrusion in the Indus delta is not based on the factual data. Many studies indicate that presently the Indus estuary is only limited to the lower parts of the delta and gets dissipated below Aghimani gauge. Data indicates that sea water intrusion is at its maximum level now. So, Kalabagh dam cannot worsen the situation further (WAPDA, 1999, p.10). 
One more apprehension is that the existing aquifer system would be badly damaged by the sea water intrusion. The Government of Pakistan constituted an International Penal of Experts (IPOE) under the guidelines of the President General Pervez Musharraf. The three members of the IPOE were Fernado J Gonzalez, Thinus Basson and Bart Schultz (Gonzalez, Basson \& Schultz, 2005). These studies were conducted to reach consensus on the minimum required escapages below Kotri Barrage, which is the main outstanding item of the Water Apportionment Accord of 1991. According to the original report of IPOE, following is its findings and recommendation.

An escapage of $5000 \mathrm{cfs}$ (.03 MAF) at Kotri Barrage throughout the year is considered to be sufficient to check seawater intrusion, accommodate the needs for fisheries and environmental sustainability, and to maintain the river channel. The IPOE also likes to stress that only the problems of surface water are relating to the sea water intrusion. The problem of salinity in the aquifer is predominantly due to fossil water salinity from geological origin.

In this regard B. A. Malik argues the 1991 Water Accord provides for release of up to 10 MAF of flood season flow below Kotri Barrage, if sea water intrusion is extended upstream as sequel to Kalabagh dam. Groundwater in lower Sindh is already saline. Although the Sub-soil flow is slow but it is towards the sea, and with fine aquifer materials of low transmissivity, there is no possibility of degradation of water quality along the Indus (Malik, 1999).

It is also objected by the experts of Sindh that mangroves forests, which are already threatened, would be further affected adversely

It is estimated that the area of mangrove forests has been reduced from 263,000 hectares in 1977 to 153,500 hectares in 1990. It shows the reduction of 38 percent. And the remaining area is progressively degrading. The consequent ravages to the ecosystem have been exceptionally severe, in particular to the mangroves, which are its mainstay. These forests are essential for the growth of fisheries and they act as natural barriers against sea and storm surges. They check sea bank erosion and are a source of fuel wood, timber, fodder and other forest products. They provide refuge to wildlife and are a potential source of tourism. So it is most important to note that without mangroves, other elements of the ecosystem cannot survive (Kazi, 2011). As Shaheen Rafi Khan argues, the survival of mangroves directly links to freshwater. Annual water releases below Kotri Barrage are $34 \mathrm{MAF}$ on average. Out of which about 20 MAF actually reach the mangroves. The balance of 14 MAF is lost due to evaporation and diversions. On the other side Sindh Forestry Department claims that about 27 MAF is required to sustain the existing 260,000 hectares of mangroves in healthy condition. There is already a shortage of 7 MAF water. This situation has destabilized the ecosystem and damage mangrove forests. Within the framework of the Indus Water Accord, if another large dam with the storage capacity of $11 \mathrm{MAF}$ is constructed at Kalabagh to fulfill agricultural and hydropower demands, it would result in a further reduction in existing flows and aggravate an already critical situation (Khan, 2003, p. 176).

According to WAPDA (1999), the Indus delta covers an area of about 1.53 million acres. Of this, mangrove forest area is almost 0.32 million acres. In this forest, $95 \%$ of the total 
population now consists of salt tolerant species. The other species found only in small colonies near canal escapes and in the active delta areas. The active delta area covers about 294,000 acres. Out of this, mangroves cover only 7400 acres or $2.5 \%$ of the area. Rest of the area is in form of mud flats. There are many factors involved in the reduction of these forests. NED University of Engineering and Technology has carried out a study titled "What Really threatens us and our Mangroves". The results of this study show that the reduction of the mangrove is due to very small frequency of tidal inundation instead of fresh water reduction caused by upstream constructions. Other major causes are uncontrolled overgrazing and cutting of trees due to extreme population pressure. Therefore, in order to revive the mangroves, real need is for replanting salt tolerant varieties with provision for controlled doses of fresh water. Obviously, this possibility would be much enhanced with an upstream storage facility like Kalabagh. It would become possible to provide well-designed and scheduled releases downstream Kotri barrage (WAPDA, 1999, p.11). B. A. Malik, the area under active tidal inundation in lower delta is about 294000 acres. The area under mangroves is only about 7500 acres or 2.5 percent. The remaining area is consisting of mud flats. Almost all the mangroves (75 percent) survive on salt water in region east of Karachi and Rann of Kutch. Studies indicate that the decrease in the mangrove forests has primarily been due to: (a) Decrease in frequency of tidal inundation; (b) Reduction in fresh water flow caused by upstream abstractions from, starting with the construction of Sukkar Barrage in 1932; (c) Uncontrolled overgrazing; (d) And excessive cutting pressure due to the rising population of Karachi (Malik, 1999).

It is also feared that the fish production and drinking water supply below Kotri Barrage would be adversely affected. Statistics of Ministry of Economic Affairs \& Statistics, Government of Pakistan given in the following table show that after Tarbela fish production is increased which proves that this apprehension is baseless.

Table: 3: Productions of Marine Fish (Thousand Tons) in Various Years

\begin{tabular}{lrrrrrrrrr}
\hline Year & 1995 & 1996 & 1997 & 1998 & 1999 & 2000 & 2001 & 2001 & 2003 \\
& & & & & & & & & \\
Fish & & & & & & & & & \\
\end{tabular}

Despite the fact that statistical data speaks otherwise it is certainly possible with the modern technology to support Palla fish and increase its production. Such measures would be taken if required. Below the Kotri barrage, maximum groundwater is saline and not suitable for irrigation or water supply. After the construction of Kalabagh, winter supply in the river would be improved and this would assure more drinking water (WAPDA, 1999, p.12). B. A. Malik also favored the above mentioned point of view and described that there is not a single study which proves that fish production will be affected below the Kotri Barrage due to the construction of Kalabagh dam. On the contrary, there would be an enormous fish catch from Kalabagh reservoir every year (Malik, 1999). 


\section{Conclusion}

It is a fact that large dams prove useful in the economies of the developed countries. Dams only store water which is used according to the requirements. They do not consume water. Due to the climatic change, it is necessary to develop water storage infrastructure. So that water can be stored for the coming dry periods. But unfortunately, in Pakistan the construction of large dams is being opposed by the various segments of the society. Particularly Kalabagh dam has become a highly controversial project in the history of Pakistan. The provinces of Khyber Pakhtunkhwa and Sindh are opposing the dam. The evidence shows that the objections of these provinces are baseless. Various studies have proved that the reservations over the dam are groundless. Even, the International Panel of Expert (IPOE), with the consent of the both provinces was appointed to deal these reservations during the Musharraf period (1999-2008). The IPOE concluded that Kalabagh dam is a useful project for the economy of Pakistan. The wastage of water and loss of property and lives in the water flood of 2010 has also revealed the importance of the dam. It is estimated that 59 million acre feet water passed through the Kotri barrage from August 1, 2010 to September 15, 2010. It is obvious that large dams like Kalabagh dam could prove beneficial for the agro based economy of Pakistan and huge losses of flood could be avoided. But, it is mutual distrust and resentment of the provinces that limits the capacity of the state to mange water disputes. The problem of water management is not limited to the case of Pakistan but it is very common in diverse societies. Various segments of heterogeneous states have different approach and objectives. The problem is severe where the political and ethno-linguistic boundaries coincide. In such cases, it is very difficult for the central authorities to ignore or override the regional aspirations. Hence, there is a requirement of national and international mechanisms to resolve the water related issues through established norms to avoid the wastage of this precious commodity elsewhere.

\section{References}

Ahmad, S. (2004).Water resources of Indus: Case study of Kalabagh Dam (unpublished PhD's thesis). Quaid-I- Azam University Islamabad, Pakistan.

Bengali, K. (2003). The Politics of Managing Water. Karachi: Oxford University Press.

Ghori, H.K. (2005, December 23). Pagara Supports Kalabagh Dam. Daily Dawn.

Gonzalez, F.J., Basson, T., \& Schultz, B. (2005). Final Report of the IPOE for review of studies on Water Escapages below Kotri Barrage. Available online at http://www.pakwaters.gov.pk. Assessed on December 2010.

Hashmi, F. (2002, May 08). Irsa Okays Thal Canal Project: Decision taken on split vote. Daily Dawn.

Hasnain, Z. (2005, December 2). ANP Blasts Kalabagh Dam. Daily Times.

Kazi, A. (2003). Kalabagh Dam: Varying points of view. In Bengali, K (Eds.) The Politics of Managing Water (pp.182-192). Karachi: oxford university press. 
Kazi, A.(2001, March 07). Kalabagh Dam: An Ecological Disaster. The Frontier Post Peshawar.

Kennedy, C.H. (2002). Pakistan: Ethnic Diversity and Colonial Legacy. In J. Coakley (Eds.), The Territorial Management of Ethnic Conflict (pp 143-172). London: Frank Cass.

Khan, R.A. (1992). Pakistan in 1991: Light and Shadows. Asian Survey. 32(2), 197-206.

Khan, S.R. (2003). The Case Against Kalabagh Dam. In Bengali, K (Eds.) The Politics of Managing Water (pp.174-181). Karachi: Oxford University Press.

Malik, B.A. (1999, November 14). The Case of Kalabagh Dam. Daily Dawn.

Malik, B.A. (2005). Indus Water Treaty in Retrospect. Lahore: Brite Books.

Mushtaq, M. (2010). Consociationalism and Multiethnic States: Post-1971 Pakistan - a Case Study (Unpublished PhD Thesis). Bahauddin Zakariya University Multan, Pakistan.

Rais, R.B. (1993). Pakistan in 1982: Waiting for change. Asian Survey. 33(2), 129-140.

Rajput, M.I. (2005). Kalabagh Dam and Sindh: A View point. Karachi: Wahid Art Press.

Salman, M.A. \& Uprety, K. (2005). Conflict and Cooperation on South Asia's International Rivers. Washington: World Bank.

WAPDA. (Pakistan Water and Power Development Authority). (1999). Kalabagh Dam Project, [Online]. Available at: http://www.wapda.gov.pk,/pdf/KBDAM.pdf. Accessed on December 2010

\footnotetext{
i - Pakistan is an important country of Southeast Asia. It got its freedom from the British on $14^{\text {th }}$ of August 1947 after the partition of united India. It comprises four provinces and federally administered tribal areas. Most of the country is located in Indus River Basin. Its economy largely depends on agriculture. Due to the arid and semi arid climatic conditions, its agriculture mostly depends on irrigation system which is developed on the Indus River System. Indus River System comprises on its eastern tributaries, the River Jhelum, the Chenab, the Ravi, the Sutlej and the Bias and western tributaries, the Kabul, the Kurram, the Tochi and many other small rivers. In 1960, it signed an agreement (Indus Water Treaty) with India on the sharing of the waters of the Indus River System.

ii - Smaller units of the federation of Pakistan (Sindh, Khyber Pakhtunkhwa and Balochistan) believe that they are being deprived from the rights, given by the constitution of the Islamic Republic of Pakistan. They are asserting for maximum provincial autonomy. They have so many reservations on the issues like NFC award, meager representation in civil and military bureaucracy, Indus River water sharing formula, role of Indus River System Authority and the construction of Kalabagh dam Project.

iii - See for example (a) Resolution No.50, put by Akhtar Mengal and passed on 6-10-1994 2 by Balochistan
} 
Assembly, (b) Resolution No 04, put by Begum Nasim Wali Khan and Passed Unanimously in the Provincial Assembly of Khyber Pakhtunkhwa in the meeting held on 20-12.1988, (c) Resolution No 251, put by Abdul Akbar Khan and Passed Unanimously in the Provincial Assembly of Khyber Pakhtunkhwa in the meeting held on 30-5-1991, (d) Resolution No 26, put by Haji Muhammad Adeel and others and Passed Unanimously in the Provincial Assembly of Khyber Pakhtunkhwa, in the meeting held on 18-11-1993, (e) Resolution No 409, Put by Dr.Abdul Wahid Somoro, and Passed Unanimously in the Provincial Assembly of Sindh, in the meeting held on 14-6-1994. The resolutions shared the text and demanded to abandon the project of Kalabagh dam to 'remove the misgivings' of the people of Pakistan.

iv - Punjab Assembly unanimously passed another resolution in favour of the construction of Kalabagh dam on $5^{\text {th }}$ October 2010. The resolution also stated that the federal government should work to build consensus among the provinces of Pakistan. The Daily Dawn, October 6, 2010.

v - The Daily Nawa-i-Waqt, September 21, 2010.

vi - Ibid.

${ }^{\text {vii }}$ Rajput, M.I. (2005), Kalabagh Dam and Sindh: A View point. Karachi: Wahid Art Press, Karachi. (For example: I. Akhtar Hussain Committee, in 1968, ii. Fazale Akbar Committee in October 1970, iii. Halim Commission, in 1977 etc).

viii Under the article of 153 of the constitution of Pakistan, CCI is constitutional body comprising of the Chief Ministers of the provinces and an equal number of members from the federal government to be nominated by the Prime Minister from time to time. Under the article 155 of the construction of Pakistan, the CCI may receive any complaint by the federation or any province regarding any executive act or legislation taken or passed or proposed to be taken or passed, or the failure of any authority to exercise any of its power with respect to the use and distribution or control of water. On receiving a complaint, The CCI will consider the matter and shall give its decision or request the president to appoint a commission. Notwithstanding any law to the contrary, but subject to the provisions of clause(5) of article 154, it shall be the duty of the Federal Government and the Provincial Government concerned in the matter in issue to give effect to the decision of the council faithfully according to its terms and tenor.

ix For detail, see “The Exit of a Chief Minister”, Dawn Overseas Weekly, Apr.14, 1988.

$\mathrm{x}$ For detail of the project se, Pakistan Water and Power Development Authority, Kalabagh dam Engineering Studies, [Online] available at http://www.wapda.gov.pk/htmls/water-index.html

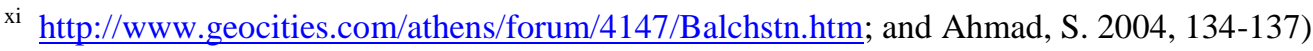

xii Hindko was not given the status of separate language and was included in the category of 'Others' in the national census repots.

xii According to the census of 1998, total population of the city was 100000 . It is also the stronghold of Awami National Party, the most furious critic of the project. 
xiv Bashir A. Malik did his graduation (B. Sc Civil Engineering) from the Aligarh Muslim University, India with distinction. He did his post graduation with specialization in Dams, Water, Power and Flood control from the State University of Lowa, USA. He also did post graduation in Hydraulic Engineering from Delft University Holland. He worked as senior advisor irrigation UNO (FAO) in Rome, Iraq, Egypt, Yemen and Liberia. He also worked as Chief Technical Advisor of Associated Consulting Engineer and Mogan Irrigation Project, Iran. He was director Tarbela Dam and Indus Basin Projects of WAPDA. He retired as Chief Technical Advisor of United Nations. About 100 papers on irrigation and dams have been published in world repute journals. Bashir A. Malik, Indus Water Treaty in Retrospect, ( Lahore: Brite Books, 2005) p. 1 